\title{
Governability of High-Value Fisheries in Low-Income Contexts: a Case Study of the Sea Cucumber Fishery in Papua New Guinea
}

\author{
Kate Barclay ${ }^{1}$ (D) $\cdot$ Michael Fabinyi $^{1} \cdot$ Jeff Kinch $^{2} \cdot$ Simon Foale $^{3}$
}

Published online: 28 June 2019

(C) The Author(s) 2019

\begin{abstract}
High demand and prices in global markets for luxury seafood fished by coastal communities in low-income contexts causes overfishing. There are few alternatives for fishers to earn money, most institutions for controlling effort are weak, and markets are beyond the control of fishing states. The mismatch between desires for development and governance measures to enable that development is shared across many high-value low-income contexts. Using the sea cucumber fishery of Papua New Guinea as an example, this paper illustrates how the interactive governance framework provides a holistic approach to revealing governability limits and opportunities. Analysis of the system to be governed demonstrates that development for coastal communities is fundamental to the fishery as a motivating force and as a principle legitimising actions within the fishery and its management. This analysis highlights the fact that fisheries management is based on the assumption that an open fishery will lead to development, due to its economic value. However, money does not equal development. For this and other similar fisheries to increase development in coastal communities, issues not usually considered within the purview of the management of fisheries must be addressed, including gendered and intergenerational decision-making and income distribution, financial planning and government provision of infrastructure and services.
\end{abstract}

Keywords Development $\cdot$ Governability $\cdot$ Human dimensions $\cdot$ Interactive governance

\section{Introduction}

As global fishery trade expands (Gephart and Pace 2015), one of the problems facing fisheries management is how to effectively manage high-value fisheries in low-income contexts. Dried sea cucumbers (often called beche-de-mer), shark fins,

Kate Barclay

Kate.Barclay@uts.edu.au

Michael Fabinyi

Michael.Fabinyi@uts.edu.au

Jeff Kinch

kinch.jeff@gmail.com

Simon Foale

Simon.Foale@jcu.edu.au

1 Faculty of Arts and Social Sciences, University of Technology Sydney, PO Box 123, Broadway, NSW 2007, Australia

2 National Fisheries College, PO Box 239, Kavieng, New Ireland, Papua New Guinea

3 College of Arts, Society and Education, James Cook University, Townsville, QLD 4811, Australia live fish and other high-value fishery products from lowincome communities display a pattern of serial depletion, whereby high prices and demand overwhelm the capacity of sustainability institutions in source countries (Anderson et al. 2011; Berkes et al. 2006; Eriksson et al. 2016; Prescott et al. 2017; de Sadovy Mitcheson et al. 2013). These fisheries create economic opportunities for coastal communities that have few alternative livelihood opportunities (Jentoft et al. 2010). The species being fished, however, play important ecological roles and are becoming vulnerable and endangered (de Sadovy Mitcheson et al. 2013; Uthicke 2001; Purcell et al. 2016b). Attention to improving governance is an urgent priority for fisheries managers and fishing communities. This paper examines the governability of one such fishery: sea cucumbers in Papua New Guinea (PNG).

Overfishing in low-income contexts that supply high-value global markets is one of the 'wicked problems' of fisheries management (Jentoft and Chuenpagdee 2009). Sociopolitical and socioeconomic factors drive fishing and limit the effectiveness of conservation measures, making fisheries problems intractable (Fulton et al. 2011). Limited fisheries management capacity in low-income areas is compounded by a lack of jurisdiction over relevant activity in international supply 
chains. Governance scholars argue that improved management of fisheries requires innovative, multi-scale and multiactor solutions that go beyond traditional fisheries management measures (Berkes et al. 2006), with a greater focus on the human aspect of fisheries management (Coulthard et al. 2011; Jentoft and Chuenpagdee 2015). The human dimension of fisheries must also be included because of the desires of coastal peoples to improve their standards of living (Coulthard et al. 2011; Fabinyi et al. 2015; Foale 2001; Jentoft 2000). Such understandings have been built into various policy frameworks, including the United Nations Food and Agriculture Organisation (FAO) ecosystems approach to fisheries (De Young et al. 2008), the FAO Voluntary Guidelines for Securing Sustainable Small-Scale Fisheries(FAO 2015) and, specifically for the island Pacific region, the New Song for Coastal Fisheries-Pathways to Change: The Noumea Strategy(SPC 2015).

One aspect of the human dimension common to high-value fisheries in low-income contexts is the need to place 'development' at the centre of fisheries management. Development, as a concept, has been criticised. Decades of international development assistance has not achieved positive effects, the 'catch-up' game of development generally spells environmental disaster and the notion is derogatory to people from countries considered less-than-fully-developed(Schafer et al. 2009). The implementation of development typically treats problems with deeply entrenched political and economic roots as merely technical ( $\mathrm{Li}$ 2007). Nevertheless, people in lowincome situations desire development and the improved health services, education and livelihood opportunities that come with it (Foale 2001).

Development is often measured on a national scale and many of the services and infrastructure required for development are most efficiently coordinated on a national scale. Fisheries have been treated as a resource for development at a national scale (Dupont and Baker 2014; Thorpe et al. 2005). The kinds of development usually considered important for the human dimension of fisheries, however, are those visible at the scale of fishing communities.

Governance frameworks to better incorporate local-level development into fisheries management have proliferated in the literature with the sustainable livelihoods approach (Allison and Ellis 2001; Allison and Horemans 2006), the wellbeing framework (Coulthard et al. 2011; Weeratunge et al. 2014) and human rights-based approaches (Allison et al. 2012; Ratner et al. 2014; Willman et al. 2017). In practice, however, fisheries management regimes still fail to address local desires for development, focusing on the effects of fishing on the biomass of target species. One reason for this is that the fields of fish stock management and community development are separate, with distinct conceptual frameworks. In the research upon which this paper is based, the 'interactive governance' approach is used to bring the two fields together.
This approach sees governance as broader than what governments do to regulate a sector (Bavinck et al. 2013; Jentoft and Chuenpagdee 2015; Kooiman et al. 2005; Song et al. 2018b). Governance is a system with:

- diverse actors and institutions - -human and non-humanincluding state and non-state actors (such as markets or cultural norms)

- complex or 'wicked' problems requiring multidisciplinary analysis

- dynamic and interactive situations

- operation across various scales, from local to global.

Interactive governance divides the analysis into socialecological systems to be governed and governing systems. Governance arises from interactions between the system to be governed and the governing system. The system to be governed may be conceptualised as not only the fishery itself, but also the 'fish chain': the supply chain from the ecosystem to consumers. This is particularly important for high-value fisheries in low-income contexts, as the drivers for overfishing occur outside the jurisdiction of the fishery.

The goals of interactive governance are broader than fisheries management goals. They include environmental sustainability, food security, economic livelihood viability and social justice (Bavinck et al. 2013; Kooiman et al. 2005), with a fifth concern about community wellbeing emerging in later work (Jentoft and Chuenpagdee 2015, p. 744) (see Fig. 1). Four of these governance goals are about development at a community scale, so are used as reference points for discussion about governability and development.

This paper addresses the governability of high-value fisheries in low-income contexts using a case study of the PNG sea cucumber fish chain. The analysis of the system to be governed highlights how development is a factor affecting the fishery, in terms of the fishery's effect on the governance

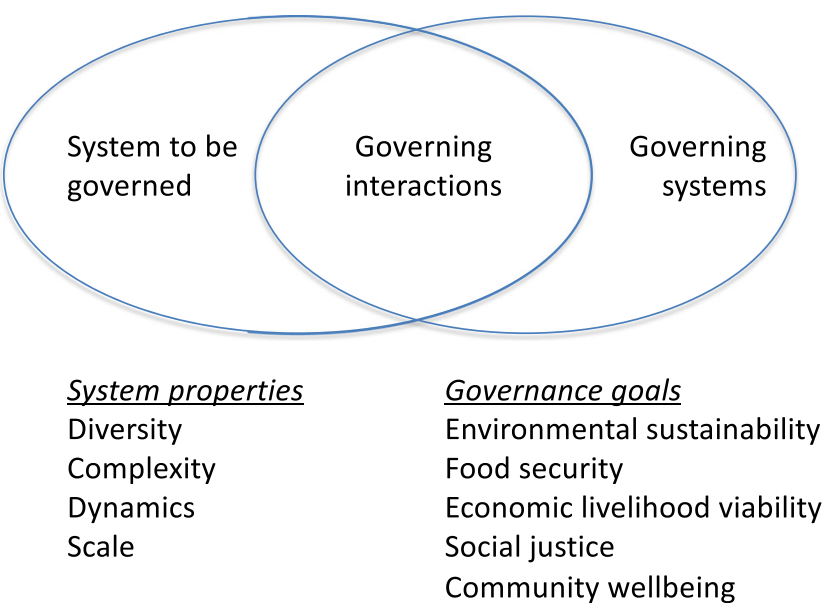

Fig. 1 Governability model (adapted from Jentoft and Chuenpagdee 2009, 2015) 
goals of food security, economic livelihood viability, community wellbeing and social justice. The analysis of the governing system highlights how development is not addressed and how it could be, by bringing development for fishing communities and fishery management into one conceptual framework and illuminating interrelationships.

Regional markets for BDM have existed for centuries, and expanded greatly since the 1980s with growing incomes in the main market, China. In the period from the 1990s to 2010 approximately 4-5000 t of dried sea cucumber were imported annually to Hong Kong, the world centre for the BDM trade (Eriksson et al. 2015). Sea cucumbers are relatively easy to harvest and process, even in remote locations. Once dried $\mathrm{BDM}$ is shelf stable, and is high value relative to its size and weight, so it is an ideal cash-earning commodity for PNG coastal communities, for whom cash-earning opportunities are extremely limited. Increasing prices and more buyers entering the trade in PNG in the 2000s led to overfishing. In 2009 the PNG National Fisheries Authority (NFA) closed the fishery to allow stocks to recover, reopening it in 2017. According to NFA records, in $2009533 \mathrm{t}$ of BDM with a total value of US $\$ 12$ million were exported from PNG. In 2018, the second year after reopening, $1109 \mathrm{t}$ of BDM with a total value of US\$25.5 million were exported from PNG.

\section{Methods and Data}

The research for this paper employed a qualitative methodology centered around interviews conducted in PNG, China and Australia (including 58 individual interviews and four group interviews with approximately 125 fishers), three stakeholder workshops (involving approximately 75 people in total) and a review of policy documents, legislation, scholarly literature and technical reports on sea cucumber fisheries and the BDM trade. The total number of participants including individual and group interviews and workshops was approximately 260 . The individual and group interviews were semistructured with targeted questions for each stakeholder group. Interviewees were asked open-ended questions about: their role in the supply chain; prospects for making the sea cucumber fishery sustainable; and their relationships with other stakeholders, including financial arrangements along the supply chain. Interviews were conducted during fieldwork visits to PNG, Hong Kong and mainland China and also remotely by phone, Skype and email. Stakeholder workshops also constituted part of the methodology. The inception workshop held in Kavieng, in New Ireland Province at the outset of the project brought together experienced coastal fisheries managers from NFA, researchers, staff from conservation organizations, exporters and coastal and island resource owners. It operated like a key informant focus group as the basis for designing the project fieldwork. Two culmination workshops were held to present draft findings and receive feedback to validate the findings, one in Manus with fishers and resource owners, and another in Port Moresby with NFA staff. Four group interviews with fishers were conducted; one with five men from Brooker Island (Louisiade Archipelago) conducted in Alotau, in Milne Bay Province, and three with large groups of 40 or more people (men and women) in three fishing villages on the south coast of Manus Island. Fieldwork constraints precluded individual interviews with fishers for this project, but two authors have previously conducted extended fieldwork in sea cucumber fishing communities (Kinch 2004; Foale 2005; Kinch et al. 2007) and their background knowledge influenced this study. Eight PNG exporters from two provincial capitals and the national capital Port Moresby were also interviewed (see Fig. 2). Thirty Chinese trading companies and trade representative organizations were interviewed in Hong Kong, Guangzhou, Shanghai and Beijing (results from this analysis were published in Fabinyi et al. 2017). PNG government interviews included people from the NFA, Customs, and provincial governments. Sixteen interviews were with key informant consultants, researchers and staff from conservation organizations with specialist expertise on coastal fisheries and/or the beche-de-mer trade specifically.

A key part of the desktop review portion of the study was a close examination of the old sea cucumber Fishery Management Plan that had been in place while the fishery was open to 2009, the new Management Plan that was revised twice during the moratorium period, and technical reports about the fishery and trade, including a review of the legal and policy framework of fisheries management for sea cucumbers in PNG and internationally (Waddell and EDO 2016).

Due to the fishery having been closed since 2009 at the time of our interviews in 2015 , our interviews were about how the fishery had operated prior to 2009. Our questions were not about precise catch amounts or prices so the sixyear gap did not constitute a significant problem for the accuracy of answers. Our questions were about the broad operations of the sea cucumber fishery and the beche-de-mer trade, and relations among actor groups. We were able to verify interview data by triangulating it with reports written while the fishery was still open.

\section{The System to Be Governed}

For hundreds of years, BDM have been sold throughout southern China and South-East Asia for health reasons and as a luxury dish (Akamine 2005). Over the last three decades, the market for BDM has grown with economic growth in China and prices have increased, resulting in serial stock depletions (Eriksson et al. 2015). Retail markets for BDM around China vary greatly. Hong Kong and southern China are established markets for tropical BDM. In northern China, 


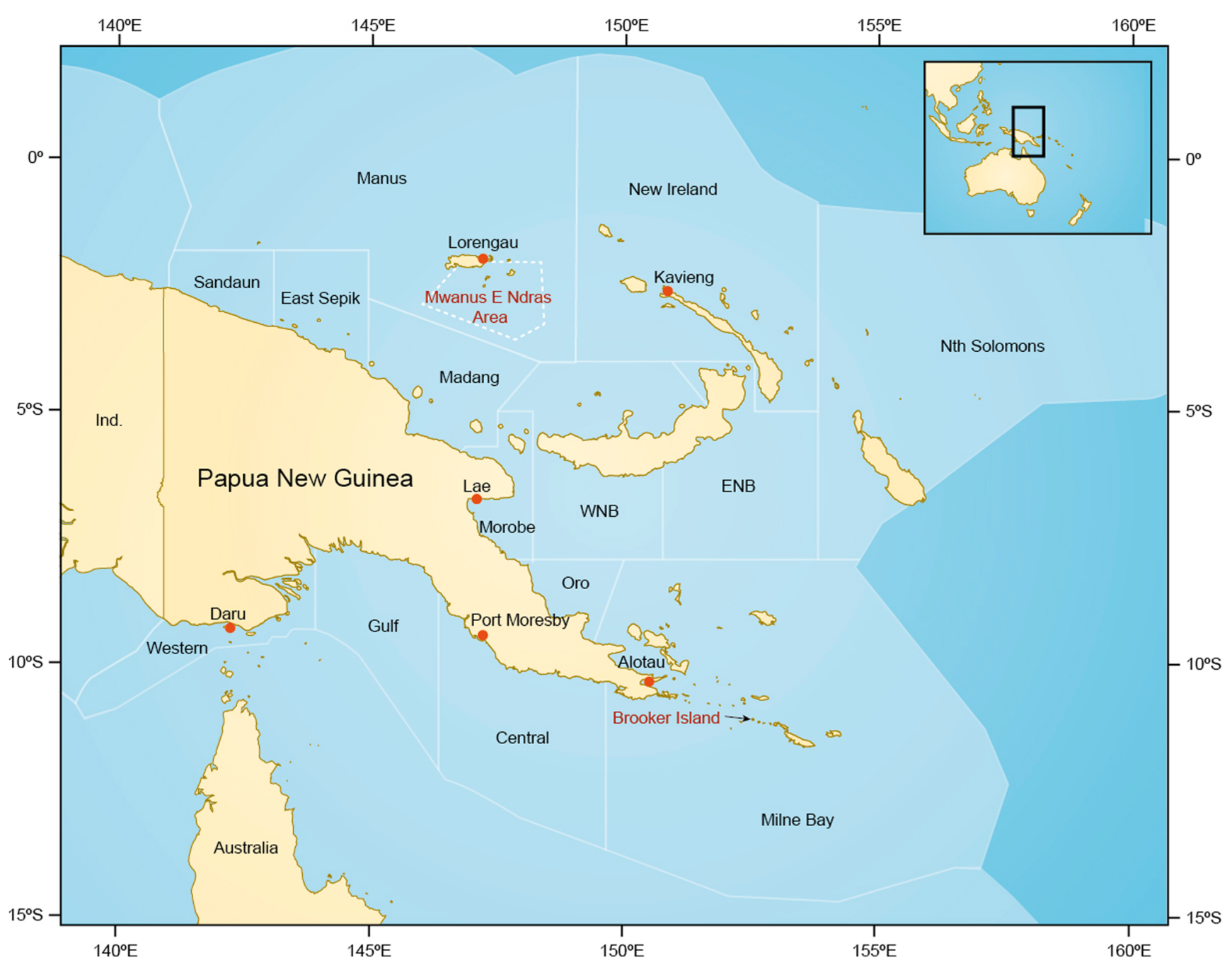

Fig. 2 Map of PNG provinces

tropical BDM is less popular compared to the temperate Japanese spiky sea cucumber (Apostichopus japonicus). As Chinese wealth rises, there is continued and increasing pressure for BDM, as markets for lower-value species and new species are growing, spreading fishing pressure to other species (Fabinyi et al. 2017; Purcell et al. 2018).

The high value of BDM and the lack of alternative income opportunities in low-income coastal fishing communities means that artisanal fishing effort does not decline after stocks have been ecologically overexploited (Bell et al. 2008; Friedman et al. 2011; Mangubhai et al. 2016; Toral-grandaet al. 2008). Surveys in PNG in the 2000s demonstrated that sea cucumber stocks were severely overfished (Skewes et al. 2002; Friedman et al. 2009; Hamilton and Lokani 2011). As noted above, in 2009, the fishery was closed to allow stocks to recover and was reopened in 2017.

The PNG sea cucumber fish chain is diverse and complex, operating across multiple scales, from local to global (see
Table 1 and Fig. 3). Development for coastal communities affected the fishery in several areas (italic areas in Table 1).

Opportunities to earn money in PNG are limited in villages far from main transport routes (Gibson and Rozelle 2003). The sea cucumber fishery is a rare opportunity and if governed well is potentially an avenue for development. Once processed by boiling and drying by smoking or sun-drying, or using salt, they are shelf stable for several months. Sea cucumbers can be caught and processed locally, without expensive or technical equipment (Kinch et al. 2008; see Figs. 4, 5 and 6).

The fishing node of the PNG sea cucumber fish chain varies across diverse geographies and species and according to factors such as the proximity of fishing grounds to living areas and proximity to buyers and exporters. Sandfish (Holothuria scabra) live in seagrass in shallow waters, so this fishery includes children, women, men and the elderly gleaning sea cucumbers. White teatfish ( $H$. fuscogilva) live in deeper waters and are caught by free diving by younger men. Almost all fishing was small-scale and conducted by 
Table 1 PNG BDM: Properties of the system to be governed

\begin{tabular}{|c|c|c|}
\hline & Social & Natural \\
\hline Diversity & $\begin{array}{l}\text { Fishery type: all local small-scale informal, no industrial, medium or } \\
\text { large scale, no (legal) foreign } \\
\text { Participation in fishing, processing, selling: men and women, old and } \\
\text { young, including children } \\
\text { Product variation: } 20+\text { species, varied quality } \\
\text { Exporter types: provincial, Port Moresby or overseas-based, mainly } \\
\text { non-PNG ethnicity } \\
\text { Market destinations: virtually all export to east and southeast Asia, } \\
\text { domestic only to a few restaurants } \\
\text { Market variation: mature high-value markets taking few established } \\
\text { species, new markets include low-value, varied species }\end{array}$ & $\begin{array}{l}\text { Habitats: estuarine, sea grass, reef and sandy bottom at varied } \\
\text { depths } \\
\text { Species numbers: } 20+\text { sea cucumber species targeted commercially } \\
\text { Species variations: differ in habitats, spawning seasons, growth } \\
\text { rates, conversion rates from wet to dry }\end{array}$ \\
\hline Complexity & $\begin{array}{l}\text { Fishery access: democratic while sea cucumbers are available in } \\
\text { shallow waters close to home, dominated by young men when } \\
\text { overfishing turns it into a dive fishery far from home } \\
\text { Supply chains: Complex, varied and sometimes very long } \\
\text { Trade legality: Importation via Hong Kong largely illegal to avoid } \\
\text { tariffs, greatly impedes transparency and traceability }\end{array}$ & $\begin{array}{l}\text { Availability: white teatfish protected from overfishing by depth } \\
\text { range, other species not } \\
\text { Species recognition for monitoring: many species look similar in } \\
\text { dried form, making monitoring at trade node of chain and } \\
\text { traceability difficult }\end{array}$ \\
\hline Dynamics & $\begin{array}{l}\text { Fishing communities: high need for cash and few alternative sources } \\
\text { of cash } \\
\text { Plasticity of fishing labor: diverted from food gardening to fishing } \\
\text { during open season } \\
\text { Politics of fishery management: strong pressure to reopen the fishery } \\
\text { and allow heavy fishing } \\
\text { Trading: high prices and high demand } \\
\text { Politics of trading: desire for PNG nationals to replace involvement } \\
\text { of non-PNG nationals in trading } \\
\text { Markets: Chinese economic upturns and downturns } \\
\text { Politics of consumption: Chinese government policy on corruption } \\
\text { with knock-on effects on luxury seafood consumption }\end{array}$ & $\begin{array}{l}\text { Resilience to fishing: easily overfished species, overfishing in } \\
\text { some areas has reduced capacity for stocks to recover } \\
\text { Climate change: presumably some effects, but as yet unclear } \\
\text { Aquaculture: stock enhancement and ranching possible but } \\
\text { commercial viability untested } \\
\text { Ecological impacts of overfishing: sediment and water quality } \\
\text { changes possible, reduced bioavailability of calcium }\end{array}$ \\
\hline Scale & $\begin{array}{l}\text { Fishery: dispersed throughout coastal areas of the country } \\
\text { Trading in PNG: consolidated in towns and cities } \\
\text { End markets: mostly east and southeast Asia region, some global } \\
\text { Feasible locations for management interventions: fishery too } \\
\text { dispersed in remote areas without government presence, points of } \\
\text { export concentrated in towns and cities, points of import also } \\
\text { concentrated, end markets very dispersed }\end{array}$ & $\begin{array}{l}\text { Connectivity: by habitat and species appear relatively localised } \\
\text { (ongoing scientific inquiry on this topic) }\end{array}$ \\
\hline
\end{tabular}

Italic areas indicate where community-scale development issues affect the operation of the fishery

Papua New Guineans in coastal and island areas. Processing and trading sea cucumbers in villages was conducted by men and women of all ages. Post-harvest handling determines product quality and, therefore, price (Purcell et al. 2016a). Exporters advised on and often finished the processing to improve quality and dryness before shipping. The first point of BDM sale included local buyers and buyers who came to the village from provincial towns. In other cases, fishers took their BDM to town and sold directly to exporters.

In the early $2000 \mathrm{~s}$, demand and prices increased and more buyers entered the market. For good quality sandfish, the price fishers were paid rose from USD17 in 1991 to USD37 in 2004. For the same period, the price of white teatfish went from USD8 to USD31 and black teatfish $(H$. whitmaei) from USD8 to USD19 (Kinch 2004). From the late 1990s, the PNG sea cucumber fishery shifted from low-volume high-value to high-volume low-value, as high-value species were fished out and new markets for low-value species expanded (Kinch et al. 2008).

\section{BDM and Development in Coastal Communities}

Development is important at various points in the system to be governed, particularly with fishers' impetus to continue fishing due to lack of other cash earning opportunities and the high value of BDM. Villagers and interviewees from other stakeholder groups saw coastal villagers as the rightful owners of the resource and argued they should be the main beneficiaries of the fishery. Government interviewees were concerned about environmental sustainability, but framed the issue in terms of sustainable livelihoods for coastal and island villagers (Foale 2001; Foale et al. 2016). The first objective of the 2018 National Beche-de-mer Fishery Management Plan is to 'manage the fishery for the long-term economic benefit of coastal and island communities', with biological sustainability the 
second objective (PNG Government 2018, Section 3). Traders, including some interviewed in China, echoed the perceptions of other stakeholder groups that Papua New Guineans, especially villagers, should be the primary beneficiaries of the trade. The exporters interviewed in Alotau stressed the importance of BDM as an income source for people from the outer islands. As the fishery increased in 2000, the Governor of Milne Bay Province stated:

[T] he simple fact [is] that many thousands of my people who depend on beche-de-mer as their only source of cash income cannot be penalised by Port Moresby based academics looking at only one side of the picture. Conservation must be a balance between developing a resource and the legitimate needs of the resource owners (Anonymous 2000).

After the 2009 moratorium, coastal villagers struggled economically (Vieira et al. 2017) and pushed, via politicians and the media, to reopen the fishery (Anonymous 2015).

\section{Food Security and Viable Livelihoods}

Food security is one of the development-related values most discussed for small-scale fisheries. Periodic episodes of food shortage have been a long-term problem in PNG (Mogina 2001), particularly in rural areas with high population density (Foale et al. 2011). A strong indicator of development is the elimination or reduction of food shortages. Sea cucumbers are not a source of food for most Papua New Guineans, but the connection between fishing and food security is often about using the proceeds from sales of fish to purchase food, rather than direct subsistence practices (Fabinyi et al. 2017). This point resonates with comments from interviewees and observations from previous studies that there was more food during the sea cucumber fishing season, as BDM sales meant the Papua New Guineans could purchase food (Kinch et al. 2007). However, anthropologist, Anders Rasmussen noted that hunger remained a feature of life during the sea cucumber closed season in Manus in the 2000s (Rasmussen 2015). Hunger was also common during the closed season in several island areas in Milne Bay (Kinch 2004). This

Fig. 3 PNG BDM fish chain

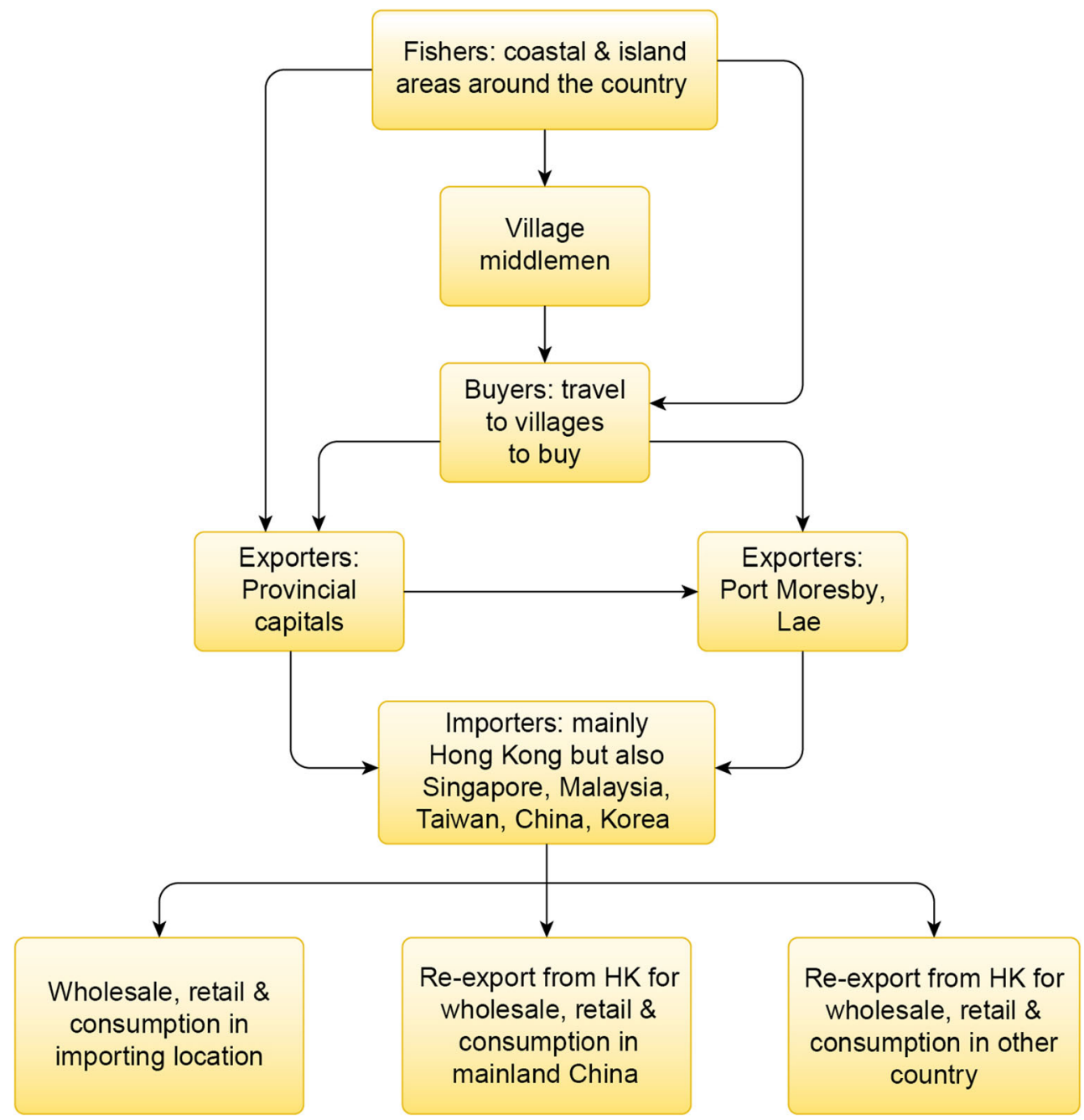


indicates that the proceeds from BDM only alleviated food shortages during the open season, and did not fix the problem of precarious food security during periods when the fishing was closed, through savings or investments in food systems, for example.

The relationship between fishing for sea cucumbers and having money for food security has an added complexity; in that, time spent fishing for sea cucumbers means less time spent on other food producing practices. Improved food security through better capacity to buy food coexists with decreased food security through reduced capacity to produce food. Labour uses in Pacific Island countries are flexible. One way people have protected themselves against a problem in an economic activity is to have several options and devote
Fig. 4 Sea cucumber catch in a canoe near fishing village. Photo credit: Simon Foale

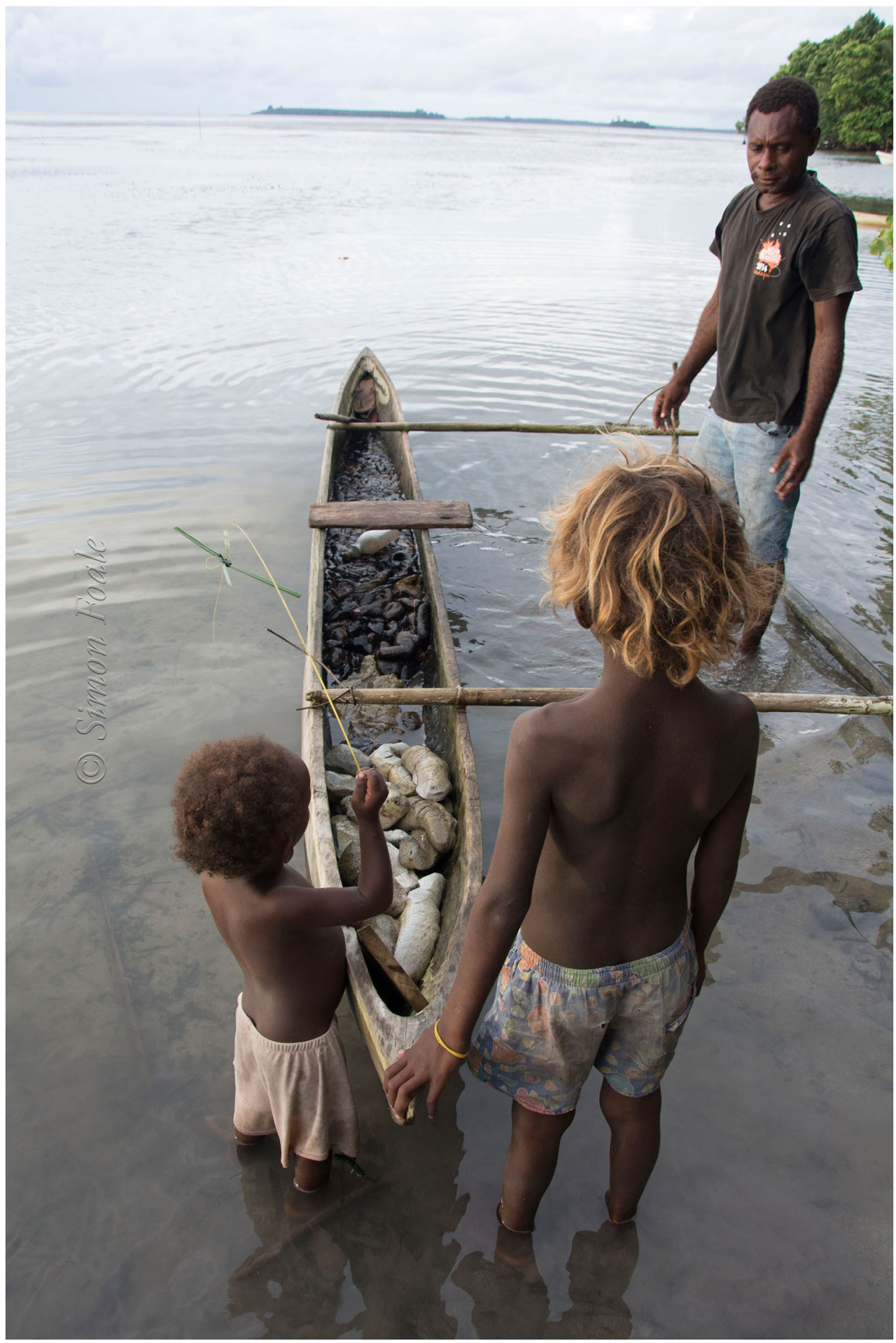


time to whichever is working best. Social obligations have high priority and people are often diverted from food producing tasks by communal tasks, such as funerary rites (Macintyre 2011). On Ware Island, and likely in other places as well, the BDM trade contributed to longer term food insecurity, as when the sea cucumber fishery was open people ished more, bought more food and reduced garden labour. When the fishery closed, their gardens were not as productive. Longer term reductions in gardening resulted in loss of skills and knowledge (Foale 2005). Although there is considerable variation and debate in the wider literature over the ways fisheries trade can contribute to food security (Béné et al. 2016), our evidence indicates BDM may have reduced food security in some areas of PNG, resonating with findings from other high-value fisheries in Melanesia (Kinch et al. 2006) and from other sources of cash income such as mining (Macintyre et al. 2007).

Did BDM contribute to viable livelihoods? It is estimated that, in the 1990s, BDM accounted for just under $50 \%$ of income on Brooker Island (Kinch et al. 2008). Villagers from Manus Island stated in interviews that, during the fishing season, BDM production was the highest priority activity in the village, as it brought more money than any other sources. By contrast, during the closed season, villagers struggled financially. If the fishery were to be governed sustainably, BDM could be a seasonal part of viable livelihoods.

\section{Community Wellbeing and Social Justice}

On Ware Island in the Milne Bay Province, the BDM trade resulted in some tangible contributions to community wellbeing in the form of overall improvements to housing standards and the construction of four new teachers houses for the school. Villagers spent large amounts of BDM cash on fuel, dinghies and outboard motors (Foale 2005). In Ontong Java, in nearby Solomon Islands, fishers bought solar panels with BDM money, improving power to their communities (Christensen 2011; Christensen and Mertz 2010). There remained ongoing community problems with wellbeing in villages visited for fieldwork that had not been alleviated by sea cucumber income, including lack of infrastructure for water supplies during the dry season and poor access to schooling and health care services, which are to be provided by the national and provincial governments.

Although interviewees unanimously agreed that income from BDM was vital for fishing families, the social effects of cash from BDM were also discussed. When asked what BDM income was used for, interviewees from Manus villages said they used it for food, education, expenses for their children and savings. One man said that sometimes the money was not used 'wisely' and he hoped people would learn from past mistakes and manage their income better when the fishery reopens. In separate interviews, Government Official A said that, when the BDM fishery was open, fishing areas and nearby towns were like 'boom towns'. Official D said she felt the

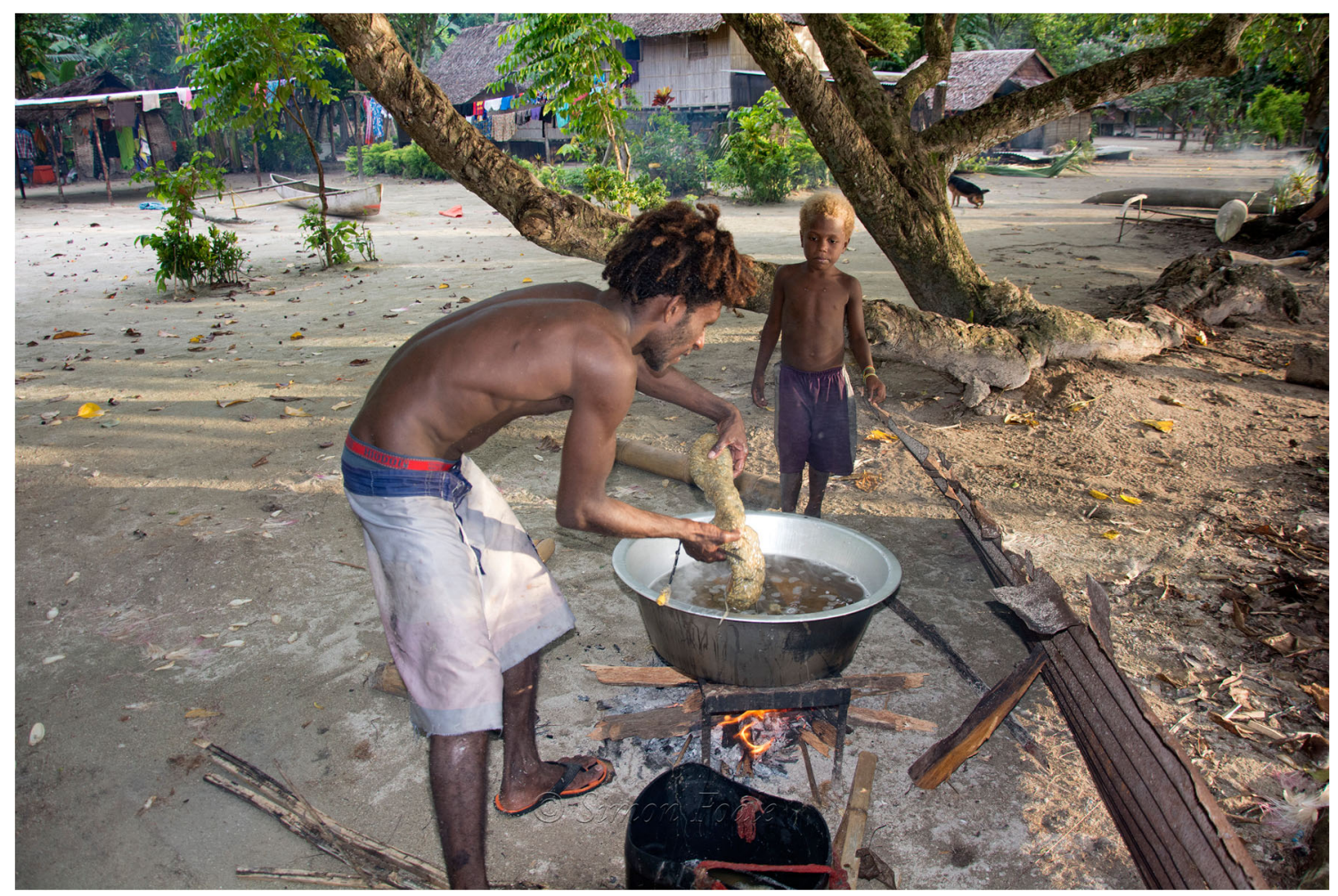

Fig. 5 Sea cucumber being processed in a village, boiling stage. Photo credit: Simon Foale 


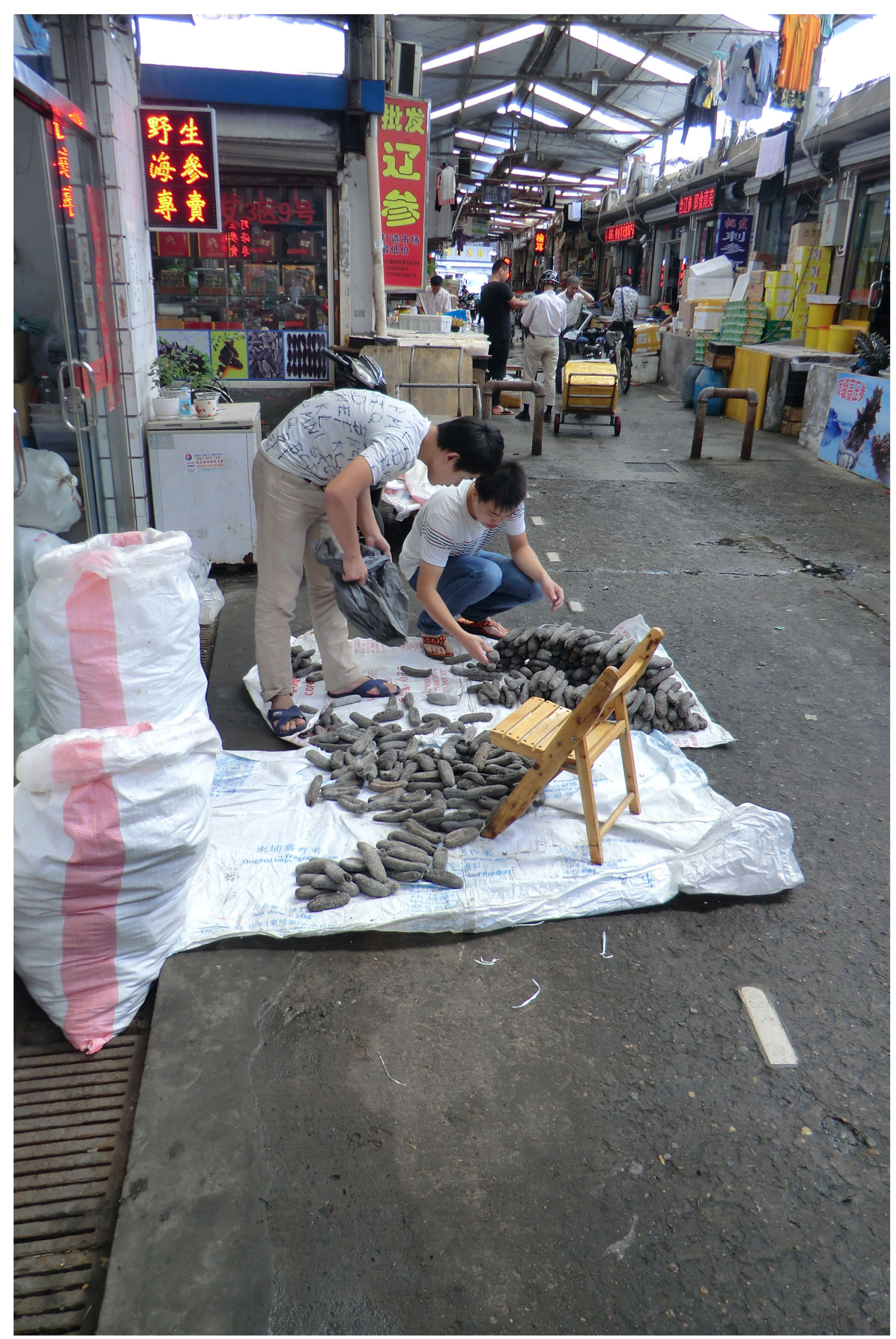

Fig. 6 Dried sea cucumber being graded at a trading business in China. Photo credit: Michael Fabinyi 
money was often 'misused' by young people. According to Exporter B, when fishers received a large payment, they spent it on alcohol, gambling and transactional sex. Similar points were raised by participants at the project inception workshop.

In PNG and other Melanesian countries, when cash has flowed into villages from logging, mining or fishing, negative social effects have been noted, including binge drinking and socially unaccepted sexual liaisons (Banks 2014). Increased alcohol consumption was one of the results of the BDM trade (Kinch et al. 2007). In the Western Province in the Solomon Islands, most money from BDM was spent on alcohol (Kinch et al. 2006; Ramofafia et al. 2007). Similar patterns of spending were noted in Ontong Java in Solomon Islands, with social disharmony arising from the ways young men used their income (Christensen 2011; Christensen and Mertz 2010; Rasmussen 2015). Unpublished data from a study in the Tigak Islands in New Ireland Province discovered that, when the season opened in 2017, some people 'went a bit crazy' with their first experience of having large amounts of cash and used most of it on recreation. Many married men surveyed provided money for household needs, in addition to buying alcohol. Several households surveyed substantially improved their housing. Some younger people donated part of their catch to their elders for them to process and sell for themselves (personal communication, Cathy Hair, June 2018).

One explanation for these problems is that most of the income was going to young men. When sea cucumbers were available close to the surface and within walking distance of the village, the fishery was open to women, children and older people and the income was spread evenly. In 2017, after stocks in shallow waters near villages recovered, the fishery reverted to this egalitarian mode (Hair et al. 2018). In the years preceding the moratorium, when accessible grounds were fished out, it was mainly a dive fishery requiring boats. Due to the physical demands of diving, the fishery became dominated by younger men with access to boats. One social problem arising from a fishery dominated by young males was that older senior men felt challenged and resentful of young men controlling so much of the village income, giving rise to conflict (Kinch et al. 2007; Rasmussen 2015). The tendency of young men to use their money for personal entertainment, not family, has been noted in PNG (Macintyre 2011) and internationally (Chaaban and Cunningham 2011; UN Women Fiji 2014). Problems arising from a lack of money for food, education and health fall disproportionately on women, due to the gendered division of household responsibilities. Women also bear the brunt of any domestic violence that may result. Although most interviews reflected the public desire for the fishery to reopen, one woman from Manus commented: 'Me, I don't want the fishery to reopen. We are better off without all the problems it brings'.

\section{Summary}

PNG's sea cucumber fishery increased income to fishing villages but overall did not give rise to significantly improved food security, livelihoods, community wellbeing or social justice. It led to a complex set of outcomes, including some improvements and some problems for community development. This finding aligns with socioeconomic surveys from several Pacific Island countries, suggesting that family income from fishing has not significantly benefited development indicators (Foale 2008; Kaly 2005; Purdy et al. 2017).

This study was a qualitative governance analysis. Further investigation is required to better understand the dynamics and measure development effects. It can be argued that having the fishery open does not ensure development. Therefore, in addition to governance for environmental sustainability, active governance is required for fishery income to translate into development. Having accepted that community development is essential for small-scale fisheries, the next challenge is establishing how government-led and community-based resource management can promote development. Our research shows that for the PNG sea cucumber fishery the key questions are: How is food security best promoted within the mix of cash income and seasonal subsistence production? How do communities manage gender and intergenerational relations to resolve disputes over the distribution and use of BDM income? How do they ensure some income goes to long-term investments in community wellbeing? How can governments provide the infrastructure and services to support community development? The following section examines the extent to which these questions were addressed in the PNG sea cucumber fishery governing system.

\section{Addressing Development in the Governing System}

There are many different governing interactions along a fish chain. The wider project from which this paper is drawn considered the full range of governance initiatives (see Barclay et al. 2016). For the purposes of this paper we focus on three main areas where development is a factor in governability: intergovernmental fisheries initiatives, fisheries management by government and community-based resource management (CBRM).

\section{Intergovernmental Fisheries Initiatives}

The recognition that development is a foundational value for coastal fisheries has been articulated in policy documents from intergovernmental organisations, such as the international Small-Scale Fisheries Guidelines (FAO, 2016) and, for the Pacific Islands, the Noumea Strategy(SPC 2015; also known 
as the New Song) and the Melanesian Spearhead Group Roadmap for Inshore Fisheries Management and Sustainable Development 2014-2023(Melanesian Spearhead Group Secretariat and Secretariat of the Pacific Community 2013). These documents focus on the rights of small-scale fishers and workers (FAO 2015) and the need to meet 'domestic development aspirations' (SPC 2015, p. 5). There are significant challenges for national adoption and implementation of these policy ideas in Pacific Island countries (Govan et al. 2013; Hanich et al. 2017). As yet, the main influence on governance of these commitments is as a shared set of aspirations for coastal fisheries governance, in which community development is central.

In addition to commitment documents, the regional organisation, the Pacific Community (SPC), has provided services to support sea cucumber fisheries, including stock assessments, assistance with the development of management plans, and extension on mariculture (SPC 2016; Bermudes 2017). SPC also publishes the Beche-de-mer Information Bulletin (available at http://www.spc.int/coastfish/en/publications/ bulletins/beche-de-mer.html). The Australian Centre for International Agriculture Research has funded work to help fishers improve the value of their product (Purcell 2014; Ram et al. 2014). These initiatives are focused on the development of sea cucumber fisheries, assuming that development for communities will flow from that. None of these initiatives deal with community development from sea cucumber fisheries. Facilitating community development from fisheries is different from resource management or technical extension. Reorienting human resources and institutions to the community development aspirations in the Noumea Strategy(SPC 2015) and Small-Scale Fisheries Guidelines (FAO, 2015) is currently a significant hurdle for national implementation.

\section{The Papua New Guinean Government}

The PNG Government has moved towards improving the management of coastal fisheries, having completed a Roadmap for Coastal Fisheries and Marine Aquaculture for Papua New Guinea: 2017-2026(PNG Government 2017). The goal of the Roadmap is 'to sustainably develop and manage our coastal resources to provide sustenance, income and ecosystem benefits to our communities and the nation at large without endangering food security or the long-term health of the resources' (p. 6). The Roadmap identifies challenges to implementing the development of fisheries and management. Central to this is a reorganisation of how the NFA and Provincial Fisheries Offices have conducted their work (pp. 6-7). Ensuring fisheries provide 'sustenance, income and ecosystem benefits' departs from the conventional focus on natural resource management and technical extension in these agencies.
The governing system for PNG's sea cucumber fisheries was based on the 2001 National Beche-de-Mer Fishery Management Plan, under the 1998 Fisheries Management Act (amended 2015) (Waddell and EDO 2016). The Management Plan was revised twice during the moratorium, with the new 2018 National Beche-de-Mer Fishery Management Plan(PNG Government 2018) now in effect. There is little in the Management Plan relating to food security, viable livelihoods, community wellbeing or social justice for coastal communities. There are provisions to allow for CBRM, as long as they are in line with the Management Plan and Fisheries Act, but not for community development. The provisions that could relate to development are to have fishing community representatives on advisory committees and to reserve occupations and business roles for Papua New Guinean nationals.

The main focus of the 2018 Management Plan is protecting sea cucumber stocks with total allowable catches for each species, and province and season closures. Because the fishery was informal and dispersed over huge areas with little government presence, measures were not applied at the fishing node of the supply chain. Regulations and monitoring, including of catches, were implemented on exporter businesses, which were accessible to government agencies in major towns and cities. Because the exporters were formal businesses, the government had leverage over them in the form of exporting licenses, permissions and a compliance bond. This management approach was pragmatic and based on the expertise of NFA staff in this fishery. On paper, the Management Plan appears effective for protecting stocks (for further discussion, see Barclay et al. 2016). However, there are capacity problems, which meant it did not prevent overfishing. The effectiveness of the public service in PNG has been deteriorating for decades (ADB 2006; Polum and Wallace 2009). The NFA has been more effective than government departments, due to reforms in the late 1990s. They became selffunding with tuna access fees, so that staff were competitively remunerated and well-resourced. ${ }^{1}$ However, subnational capacity has remained low (Kinch et al. 2011). The regulatory system for managing the sea cucumber fishery and BDM trade relies on provincial fisheries and customs officials whose bureaucratic environment was not reformed or resourced in the same way as NFA.

Government management of the sea cucumber fishery has thus focused on protecting stocks, with 'development' limited to having the fishery open and encouraging some technical extension. When findings about the need for a community development approach were raised at the project culmination

\footnotetext{
${ }^{1}$ In 2018, NFA's self-funding capacity was reduced by $90 \%$ through the Public Money Management Regularization Act(2017) that subsumes the income of state-owned enterprises and statutory authorities into consolidated revenue.
} 
workshop in Port Moresby, NFA staff responded that they recognised this need and attempted to conduct development projects in coastal and island areas, including deploying inshore-anchored fish aggregating devices, support for fishing cooperatives and funding for community groups. Because the NFA lacks community development expertise, they collaborate with other organisations who have staff trained in community development, including other government agencies and non-government organisations (NGOs), such as The Nature Conservancy and WWF (Foale and Sullivan 2013; Kinch 2005). These collaborations are largely unsuccessful, however, due to divergent interests and bureaucratic processes. Moreover, the NGO projects are usually technical initiatives ( $\mathrm{Li}$ 2007) and do not focus on the intergenerational and gender relations or economic planning needs revealed in our research as important for community development in sea cucumber fisheries.

\section{Community-Based Measures}

In addition to government management of the sea cucumber fishery, governance for development could occur through CBRM. This is not a discussion of whether CBRM can provide effective management of sea cucumber stocks (see Barclay et al. 2016; Cohen and Foale 2013; Foale et al. 2011), but whether CBRM has contributed to governance for development of the sea cucumber fishery.

Some obstacles preventing cash from sea cucumber fisheries from contributing to community development can be best managed at a community level. That is, distributional problems relating to gender and age, choices to use cash for longterm investment versus consumables and recreational activities and the balance of cash and production in food security. An important caveat to this point is that it is unrealistic to expect communities alone to achieve fisheries-related community development. Many long-term development investments are the responsibility of government. Community initiatives for development should be supported with government infrastructure and services.

Conceiving of CBRM goals as community development, as well as preventing overfishing, fits with Pacific Islander principles for resource management (Govan et al. 2009). Approaching village-level governing interactions as a community development challenge aligns with the principles behind the SSF Guidelines(FAO 2015), Noumea Strategy(SPC 2015) and the PNG Roadmap for Coastal Fisheries(PNG Government 2017). The objectives, principles and key approaches of the Roadmap (pp. 6-7) highlight the key role of communities in coastal resource management and the importance of wellbeing improvements for all groups within island and coastal societies. Environmental NGOs working on CBRM in the Pacific increasingly include development goals with conservation goals to encourage community engagement.
Fishing communities in PNG vary greatly in their potential for fostering development from CBRM of the sea cucumber fishery. The Titan Council of Chiefs group in southern Manus and Brooker Island in Milne Bay represent two ends of this spectrum (see Fig. 2). In Manus, with the help of The Nature Conservancy, several villages have, for some years, coordinated management of their sea resources under an umbrella group called Mwanus E Ndras (Almany et al. 2015). Building on this coordination, they made good income from their high value sea cucumbers and avoided overfishing in the 2017 open season (Konia 2018; personal communication Peter Waldie, August 2018). In contrast, sea cucumber fishing communities from Brooker Island have had much less external support and have not experimented with different models for coastal fisheries management. For Brooker, a continued spiral of 'boom and bust' that has characterised PNG sea cucumbers in the past appears likely (Hair et al. 2016). In some locations, communities may help drive development initiatives. In others, community-driven attempts to improve development from the sea cucumber fishery and trade appear unlikely to succeed in the short to medium term.

\section{Conclusion}

One of the central governability challenges in high-value fisheries in low-income countries is how to understand and incorporate local aspirations for development. The approach taken in this project - interactive governance analysis - is useful for addressing that challenge. This kind of analysis of a single fishery does not result in a blueprint for managing the problem of high-value fisheries from low-income contexts everywhere, but helps move beyond general statements, showing specifically where in a fishery development is an issue and indicating directions for tackling it in that context, including through government policies and practices.

Analysis of the system to be governed illuminates the importance of development as a motivating force in PNG and as a principle legitimising actions within the sea cucumber fishery and its management. All major stakeholder groups agree that the main value of the sea cucumber fishery in PNG is to enable development for fishing communities. From a conventional fisheries management perspective, the governance problem facing the PNG BDM industry is to avoid overfishing so that an ecologically sustainable fishery can bring development through income. Through applying a governability analysis, we observed that overfishing is only part of the problem. Asking whether the fishery was meeting the governance goals of food security, viable livelihoods, social justice and community wellbeing, we discovered that incomes from sea cucumbers were at best ambiguously contributing to these goals. Improving governance means reframing the problem, from sustainable development of the sea cucumber fishery, to 
sustainable development from the sea cucumber fishery. This means, in addition to preventing overfishing, and providing government infrastructure and services, it is also important to consider food security needs in the context of cash incomes, address gender and intergenerational tensions around the distribution and use of cash incomes, and balance the use of cash incomes between consumables and durable improvements to standards of living and human development. Strategies, such as the Small-Scale Fisheries Guidelines(FAO 2015), the Noumea Strategy(SPC 2015) and the PNG Roadmap for Coastal Fisheries(PNG Government 2017) can only be achieved if this kind of reframing of fisheries governance occurs.

To catalyse the reframing of fisheries governance, agencies must encompass a new skill set in community development, which is not a trivial task. There are existing approaches and knowledge about community development in other sectors (Allison and Horemans 2006; Allison et al. 2012; Coulthard et al. 2011; Song et al. 2018a). The challenge is to integrate community development approaches and knowledge with existing fisheries management skills through training, recruitment and collaboration with other organisations.

Acknowledgements We thank collaborators on the project EDO NSW, Sarah Waddell, Graeme Smith, Shashi Sharma, Pongie Kichawen, Paul Lokani and Richard Hamilton. We thank staff from the PNG National Fisheries Authority who facilitated our work, especially Leban Gisawa and the late Luanah Yaman. For reasons of space and confidentiality, we cannot name all of the participants here, but we would like to express our gratitude.

Funding The research was funded by the David and Lucile Packard Foundation (grant no. 2014-40093).

Compliance with Ethical Standards Author J. Kinch was an employee of the PNG National Fisheries Authority during the research and writing up of this project.

Ethical Approval The research was conducted with approval from the University of Technology Sydney Human Research Ethics Committee (project no. 2014000548).

Conflict of Interest The other authors have no conflict of interest in the PNG sea cucumber fishery.

Open Access This article is distributed under the terms of the Creative Commons Attribution 4.0 International License (http:// creativecommons.org/licenses/by/4.0/), which permits unrestricted use, distribution, and reproduction in any medium, provided you give appropriate credit to the original author(s) and the source, provide a link to the Creative Commons license, and indicate if changes were made.

\section{References}

ADB. (2006). Governance in Papua New Guinea-A thematic assessment. Strategy and program assessment. Manila.
Akamine, J. (2005). Role of the Trepang traders in the depleting resource management: A Philippine case. Senri Ethnological Studies, 67, 259-278.

Allison, E. H. \& Ellis, F. (2001). The livelihoods approach and management of small-scale fisheries. Marine Policy, 25, 377-388. https:// doi.org/10.1016/S0308-597X(01)00023-9

Allison, E. H. \& Horemans, B. (2006). Putting the principles of the sustainable livelihoods approach into fisheries development policy and practice. Marine Policy, 30(6), 757-766. https://doi.org/10. 1016/j.marpol.2006.02.001

Allison, E. H., Ratner, B. D., Åsgård, B., Willmann, R., Pomeroy, R. \& Kurien, J. (2012). Rights-based fisheries governance: From fishing rights to human rights. Fish and Fisheries, 13(1), 14-29. https://doi. org/10.1111/j.1467-2979.2011.00405.x

Almany, G. R., Hamilton, R. J., Matawai, M., \& Kichawen, P. (2015). Local benefits from community actions: small managed areas can help rebuild and sustain some coastal fisheries. SPC Traditional Marine Resource Management and Knowledge Information Bulletin, 35(July), 3-17.

Anderson, S. C., Flemming, J. M., Watson, R. \& Lotze, H. K. (2011). Serial exploitation of global sea cucumber fisheries. Fish and Fisheries, 12(3), 317-339. https://doi.org/10.1111/j.1467-2979. 2010.00397.x

Anonymous. (31 August 2000). Philemon calls for rethink on beche-demer moratorium. The Independent.

Anonymous. (21 December 2015). Government ban on sea cucumbers hits hard. Post Courier.

Banks, G. (2014). Papua New Guinea national human development report 2014: From wealth to wellbeing: Translating resource revenue into sustainable human development. Port Moresby, Papua New Guinea.

Barclay, K., Kinch, J., Fabinyi, M., Waddell, S., Graeme Smith, Sharma, S., ... Hamilton, R. (2016). Interactive governance analysis of the bêche-de-mer 'fish chain' from Papua New Guinea to Asian markets. https://doi.org/10.13140/RG.2.2.10787.66083

Bavinck, M., Chuenpagdee, R., Jentoft, S. \& Kooiman, J. (2013). Governability of fisheries and aquaculture: Theory and applications. Dordrecht: Springer.

Bell, J. D., Purcell, S. W. \& Nash, W. J. (2008). Restoring small-scale fisheries for tropical sea cucumbers. Ocean and Coastal Management, 51(8-9), 589-593. https://doi.org/10.1016/j. ocecoaman.2008.06.011

Béné, C., Arthur, R., Norbury, H., Allison, E. H., Beveridge, M., Bush, S., ... Williams, M. (2016). Contribution of fisheries and aquaculture to food security and poverty reduction: Assessing the current evidence. World Development, 79, 177-196. https://doi.org/10.1016/j. worlddev.2015.11.007

Berkes, F., Hughes, T. P., Steneck, R. S., Wilson, J. A., Bellwood, D. R., Crona, B. I., ... Worm, B. (2006). Globalization, roving bandits and marine resources. Science, 311(5767), 1557-1558. https://doi.org/ 10.1126/science.1122804

Bermudes, M. (2017). Regional exchange on sandfish aquaculture for restocking. SPC Fisheries, 154, 9-11.

Chaaban, J. \& Cunningham, W. (2011). Measuring the economic gain of investing in girls the girl effect dividend (The World Bank Policy Research Working Paper). Washington DC: The World Bank. https://doi.org/10.1596/1813-9450-5753

Christensen, A. E. (2011). Marine gold and atoll livelihoods: The rise and fall of the bêche-de-mer trade on Ontong Java, Solomon Islands. Natural Resources Forum, 35, 9-20.

Christensen, A. E. \& Mertz, O. (2010). Researching Pacific island livelihoods: Mobility, natural resource management and nissology. Asia Pacific Viewpoint, 51, 278-287.

Cohen, P. J. \& Foale, S. J. (2013). Sustaining small-scale fisheries with periodically harvested marine reserves. Marine Policy, 37, 278-287. https://doi.org/10.1016/J.MARPOL.2012.05.010 
Coulthard, S., Johnson, D. \& McGregor, J. A. (2011). Poverty, sustainability and human wellbeing: A social wellbeing approach to the global fisheries crisis. Global Environmental Change, 21, 453-463.

De Young, C., Charles, A. \& Hjort, A. (2008). Human dimensions of the ecosystem approach to fisheries: An overview of context, concepts, tools and methods. Food and Agriculture Organization of the United Nations, Rome, 489, 165.

Dupont, A. \& Baker, C. G. (2014). East Asia's maritime disputes: Fishing in troubled waters. Washington Quarterly, 37(1), 79-98. https://doi. org/10.1080/0163660X.2014.893174

Eriksson, H., Adhuri, D. S., Adrianto, L., Andrew, N. L., Apriliani, T., Daw, T., ... Beare, D. J. (2016). An ecosystem approach to smallscale fisheries through participatory diagnosis in four tropical countries. Global Environmental Change, 36, 56-66. https://doi.org/10. 1016/j.gloenvcha.2015.11.005

Eriksson, H., Osterblom, H., Crona, B., Troell, M., Andrew, N., Wilen, J. \& Folke, C. (2015). Contagious exploitation of marine resources. Frontiers in Ecology and Environment, 13, 435-440.

Fabinyi, M., Barclay, K. \& Eriksson, H. (2017). Chinese trader perceptions on sourcing and consumption of endangered seafood. Frontiers in Marine Science, 4(JUN). https://doi.org/10.3389/ fmars.2017.00181

Fabinyi, M., Foale, S. \& Macintyre, M. (2015). Managing inequality or managing stocks? An ethnographic perspective on the governance of small-scale fisheries. Fish and Fisheries, 16(3), 471-485. https:// doi.org/10.1111/faf.12069

Foale, S. (2001). ‘Where's our development?' Landowner aspirations and environmentalist agendas in western Solomon Islands. The Asia Pacific Journal of Anthopology, 2(2), 44-67.

Foale, S. (2005). Sharks, sea slugs and skirmishes: Managing marine and agricultural resources on small, overpopulated islands in Milne Bay, PNG (Working Paper No. 64). Canberra: Australian National University.

Foale, S. (2008). A preliminary exploration of relationships among fishery management, food security and the millennium development goals in Melanesia. Traditional Marine Resource Management and Knowledge Information Bulletin, 24(December), 3-8.

Foale, S., Cohen, P., Januchowski-Hartley, S., Wenger, A. \& Macintyre, M. (2011). Tenure and taboos: Origins and implications for fisheries in the Pacific. Fish and Fisheries, 12(4), 357-369. https://doi.org/ 10.1111/j.1467-2979.2010.00395.x

Foale, S., Dyer, M. \& Kinch, J. (2016). The value of tropical biodiversity in rural Melanesia. Valuation Studies, 4(1), 11-39.

Foale, S. and N. Sullivan (2013). Improving Livelihoods of Coastal Artisanal Fishing Communities in Madang Province, Papua New Guinea, Through Piloting Alternative Fishing Methods. Townsville and Port Moresby, James Cook University and WWF Western Melanesia Programme Office.

Friedman, K., Eriksson, H., Tardy, E. \& Pakoa, K. (2011). Management of sea cucumber stocks: Patterns of vulnerability and recovery of sea cucumber stocks impacted by fishing. Fish and Fisheries, 12(1), $75-93$.

Friedman, K., Kronen, M., Pinca, S., Magron, F., Boblin, P., Pakoa, K., ... Chapman, L. (2009). Papua New Guinea country report: Profiles and results from survey work at Andra, Tsoilaunung, Sideia and Panapompom (June to November 2006, Pacific Regional Oceanic and Coastal Fisheries Development Programme, PROCFish/C/ CoFish). Noumea, New Caledonia.

Fulton, E. A., Smith, A. D. M., Smith, D. C. \& Van Putten, I. E. (2011). Human behaviour: The key source of uncertainty in fisheries management. Fish and Fisheries, 12(1), 2-17. https://doi.org/10.1111/j. 1467-2979.2010.00371.x

Gephart, J. A. \& Pace, M. L. (2015). Structure and evolution of the global seafood trade network. Environmental Research Letters 10, 12.
Gibson, J. \& Rozelle, S. (2003). Poverty and access to roads in Papua New Guinea. Economic Development and Cultural Change, 52(1), 159-185. https://doi.org/10.1086/380424

Govan, H., Kinch, J. \& Brjosniovschi, A. (2013). Strategic review of inshore fisheries policies and strategies in Melanesia. Part II: Country reports. Port Vila, Vanuatu.

Govan, H., Tawake, A., Tabunakawai, K., Jenkins, A., Asgorceix, A., Schwarz, A., ... Obed, T. (2009). Status and potential of locally-managed marine areas (LMMA) in the South Pacific: Meeting nature conservation and sustainable livelihood targets through wide-spread implementation of LMMAs. Noumea, New Caledonia.

Hair, C., Foale, S., Kinch, J., Yaman, L. \& Southgate, P. C. (2016). Beyond boom, bust and ban: The sandfish (Holothuria scabra) fishery in the Tigak Islands, Papua New Guinea. Regional Studies in Marine Science, 5, 69-79.

Hair, C., Kinch, J., Galiurea, T., Kanawi, P., Mwapweya, M. \& Noiney, J. (2018). Re-opening of the sea cucumber fishery in Papua New Guinea: A case study from the Tigak Islands in the New Ireland Province. SPC Beche-de-Mer Information Bulletin, 38, 3-10.

Hamilton, R. \& Lokani, P. (2011). Severely overfished sea cucumbers in the autonomous region of Bougainville. SPC Beche-de-Mer Information Bulletin, 31, 12-16.

Hanich, Q., Governance, F., Leader, P., Andrew, N., Scientist, P., Amos, M., ... Deputy, F. (2017). Enabling government-empowering communities national implementation of the New Song. 10th SPC Heads of Fisheries Meeting (14-17), Noumea, New Caledonia: The Pacific Community (SPC).

Jentoft, S. (2000). The community: A missing link of fisheries management. Marine Policy, 24(1), 53-60.

Jentoft, S. \& Chuenpagdee, R. (2009). Fisheries and coastal governance as a wicked problem. Marine Policy, 33(4), 553-560. https://doi. org/10.1016/j.marpol.2008.12.002

Jentoft, S. \& Chuenpagdee, R. (2015). Interactive governance for smallscale fisheries: Global reflections. Switzerland: Springer.

Jentoft, S., Onyango, P. \& Mahmudul Islam, M. (2010). Freedom and poverty in the fishery commons. International Journal of the Commons, 4(1), 345. https://doi.org/10.18352/bmgn-lchr.157

Kaly, U. (2005). Small-scale fisheries related socio-economic survey of New Ireland Province, Papua New Guinea. Port Moresby: National Fisheries Authority.

Kinch, J. (2004). A review of the Beche-de-mer fishery and it's management in Papua new Guinea. Report commissioned by the National Fisheries Authority (NFA) from the Motupore Island research Centre (University of Papua new Guinea). Port Moresby.

Kinch, J. (2005). The Socio-economics of an European Union - Rural Coastal Fisheries Development Program Fisher Group: KarKar Island, Madang Province, Papua New Guinea. Port Moresby, University of Papua New Guinea.

Kinch, J., Carnie, G., Walton, H., Pickering, T., Jimmy, R., Numilengi, T., ... Pirape, P. (2011). Training needs analysis of the fisheries sector in Papua New Guinea. Port Moresby: National Fisheries Authority.

Kinch, J., James, M., Thomas, E., Lauhi, P. \& Gabiobu, R. (2007). Socioeconomic assessment of the beche-de-mer fisheries in the Western, Central and Manus Provinces, Papua New Guinea. Port Moresby: National Fisheries Authority.

Kinch, J., Mesia, P., Kere, N., Manioli, J. \& Bulehite, K. (2006). Socioeconomic baseline assessment for the Eastern Marovo Lagoon, Western Province, the Solomon Islands (IWP-Pacific technical report no. 35). Retrieved from https://www.sprep.org/att/publication/ 000536_IWP_PTR35.pdf. Accessed 30 Mar 2016.

Kinch, J., Purcell, S. W., Uthicke, S. \& Friedman, K. (2008). Population status, fisheries and trade of sea cucumbers in the western central Pacific. (FAO fisheries and aquaculture technical paper, no. 516), 755. Retrieved from http://www.fao.org/docrep/pdf/011/i0375e/ i0375e01.pdf. Accessed 27 Feb 2016. 
Konia, R. (20 April 2018). Manus islanders profit from bech-de-mer. The National. Retrieved from https://www.thenational.com.pg/manusislanders-profit-bech-de-mer/. Accessed 13 July 2018.

Kooiman, J., Bavinck, M., Jentoft, S. \& Pullman, R. (2005). Fish for life: Interactive governance for fisheries. Netherlands: Amsterdam University Press.

Li, T. (2007). The will to improve. Durham: Duke University Press.

Macintyre, M. (2011). Money changes everything: Papua new Guinean women in the modern economy. In M. Patterson \& M. Macintyre (Eds.), Managing modernity in the western Pacific (pp. 90-120). St Lucia: University of Queensland Press.

Macintyre, M., Foale, S. \& McKenzie, M. (2007). Teacher's guide (booklets 1-4) impacts of mining on Lihir. Canberra and Port Moresby: Solwara Research, Lihir Gold Limited.

Mangubhai, S., Nand, Y., Ram, R., Fox, M., Tabunakawai-Vakalalabure, M., \& Vodivodi, T. (2016). Value chain analysis of the wild caught mud crab fishery in Fiji. Wildlife Conservation Society and Fiji Department of Fisheries. Report No. 02/16. Suva, Fiji. https://fiji. wcs.org/Portals/82/reports/Value_chain_sea_cucumber_FIJI_Final_online_version.pdf. Accessed 31 Aug 2018.

Melanesian Spearhead Group Secretariat \& Secretariat of the Pacific Community. (2013). Roadmap for inshore fisheries management and sustainable development 2014-2023. SPC Fisheries Newsletter, (142), 39-42.

Mogina, J. (2001). Food aid and traditional strategies for coping with drought: Observations of responses by villagers to the 1997 drought in Milne Bay Province. Food Security for Papua New Guinea. Proceedings of the Papua New Guinea Food and Nutrition 2000 Conference, Papua New Guinea University of Technology, Lae, 201-208.

PNG Government. (6 June 2018). National bech-de-mer fishery management plan. National Gazette, G368.

PNG Government. (2017). A roadmap for coastal fisheries and marine aquaculture for Papua New Guinea. Port Moresby: National fisheries authority.

Polum, N. \& Wallace, M. (2009). Executive development: Learning from effective practices in the Papua New Guinea public service. Sustainable management and marketing: Australian and New Zealand academy of management (ANZAM) conference, Melbourne, Victoria, 1-4 December.

Prescott, J., Riwu, J., Prasetyo, A. P. \& Stacey, N. (2017). The money side of livelihoods: Economics of an unregulated small-scale Indonesian sea cucumber fishery in the Timor Sea. Marine Policy, 82, 197-205.

Purcell, S. W. (2014). Processing sea cucumbers into beche-de-mer: A manual for Pacific Island fishers. Noumea, New Caledonia: Southern Cross University and the Secretariat of the Pacific Community.

Purcell, S. W., Ngaluafe, P., Foale, S. J., Cocks, N., Cullis, B. R. \& Lalavanua, W. (2016a). Multiple factors affect socioeconomics and wellbeing of artisanal sea cucumber fishers. PLOS ONE, 11(12). https://doi.org/10.1371/journal.pone.0165633

Purcell, S., Conand, C., Uthicke, S. \& Byrne, M. (2016b). Ecological roles of Exploited Sea cucumbers. Oceanography and Marine Biology: An Annual Review, 54, 367-386.

Purcell, S. W., Williamson, D. H. \& Ngaluafe, P. (2018). Chinese market prices of beche-de-mer: Implications for fisheries and aquaculture. Marine Policy, 91(April), 58-65. https://doi.org/10.1016/j.marpol. 2018.02.005

Purdy, D. H., Hadley, D. J., Kenter, J. O. \& Kinch, J. (2017). Sea cucumber moratorium and livelihood diversity in Papua new Guinea. Coastal Management, 45(2), 161-177. https://doi.org/10.1080/ 08920753.2017.1278147

Ram, R., Chand, R. \& Southgate, P. (2014). Effect of harvest and postharvest processing methods on quality of beche-de-mer in the Fiji Islands. Journal of Marine Science: Research and Development, 4(3). https://doi.org/10.4172/2155-9910.1000153
Ramofafia, C., Nash, W. J., Sibiti, S., Makini, D. \& Schwarz, A. M. (2007). Household socio-economics and béche-de-mer resource use in Kia community, Isabel Province, Solomon Islands (June 2005).ACIAR/ Worldfish Center Sea Cucumber Fishery Management Project FIS/2003/051, Solomon Islands. Gizo, Solomon Islands.

Rasmussen, A. E. (2015). In the absence of the gift: New forms of value and personhood in a Papua New Guinea community. New York \& Oxford: Berghahn Books.

Ratner, B. D., Åsgård, B. \& Allison, E. H. (2014). Fishing for justice: Human rights, development and fisheries sector reform. Global Environmental Change, 27(1), 120-130. https://doi.org/10.1016/j. gloenvcha.2014.05.006

de Sadovy Mitcheson, Y., Craig, M. T., Bertoncini, A. A., Carpenter, K. E., Cheung, W. W. L., Choat, J. H., ... Sanciangco, J. (2013). Fishing groupers towards extinction: A global assessment of threats and extinction risks in a billion dollar fishery. Fish and Fisheries, 14(2), 119-136. https://doi.org/10.1111/j.1467-2979.2011.00455.x

Schafer, J., Haslam, P. A. \& Beaudet, P. (2009). Meaning, measurement and morality in international development. In P. A. Haslam, J. Schafer \& P. Beaudet (Eds.), Introduction to International Development: Approaches, Actors and Issues (pp. 2-27). Oxford UK: Oxford University Press.

Skewes, T., Kinch, J., Polon, P., Dennis, D., Seeto, P., Taranto, T., Lokani, P., Wassenberg, T., Koutsoukos, A. and Sarke, J. (2002). Research for the Sustainable Use of Beche-de-mer Resources in the Milne Bay Province, Papua New Guinea. Report prepared for the National Fisheries Authority, Port Moresby, Papua New Guinea; and the Australian Centre for international agricultural research, Canberra, Australia.

Song, A. M., Bower, S. D., Onyango, P., Cooke, S. J., Akintola, S. L., Baer, J. \& Gurung, T. B. (2018a). Intersectorality in the governance of inland fisheries. Ecology and Society, 23(2), 17.

Song, A. M., Johnsen, J. P. \& Morrison, T. H. (2018b). Reconstructing governability: How fisheries are made governable. Fish and Fisheries, 19(2), 377-389. https://doi.org/10.1111/faf.12262

SPC. (2015). A new song for coastal fisheries-pathways to change: The Noumea strategy. Noumea, New Caledonia: Pacific Community (SPC). Retrieved from http://www.spc.int/coastfish/component/ content/article/461-a-new-song-for-coastal-fisheries.html. Accessed 3 Nov 2017.

SPC. (2016). Hands-on training in sandfish and microalgae hatchery techniques. Retrieved from http://aquaculture.spc.int/index.php? option=com_content\&view=article\&id=101:-hands-on-training-insandfish-and-microalgae-hatchery-techniques\&catid=15:articles. Accessed 30 Apr 2018.

Thorpe, A., Reid, C., van Anrooy, R. \& Brugere, C. (2005). When fisheries influence national policy-making: An analysis of the national development strategies of major fish-producing nations in the developing world. Marine Policy, 29(3), 211-222. https://doi.org/10. 1016/j.marpol.2004.05.004

Toral-granda, V., Lovatelli, A., Vasconcellos, M., Conand, C., Hamel, J., Mercier, A., ... Uthicke, S. (2008). Sea cucumbers. A global review on fishery and trade (FAO fisheries and aquaculture technical paper no. 516). Retrieved from http://www.fao.org/docrep/011/i0375e/ i0375e00.htm. Accessed 30 Nov 2016.

United Nations Food and Argriculture Organisation. (2015). Voluntary guidelines for securing sustainable small-scale fisheries in the context of food security and poverty eradication. Rome: FAO. Retrieved from http://www.fao.org/3/a-i4356en.pdf. Accessed 11 Apr 2016.

UN Women Fiji. (2014). Climate change, poverty and women's economic empowerment in the Pacific. Retrieved from http://asiapacific. unwomen.org/en/digital-library/publications/2015/1/climatechange-poverty-and-women-s-economic-empowerment. Accessed 25 June 2019. 
Uthicke, S. (2001). Nutrient regeneration by abundant coral reef holothurians. Journal of Experimental Marine Biology and Ecology, 265(2), 153-170.

Vieira, S., Kinch, J., White, W., \& Yaman, L. (2017). Artisanal shark fishing in the Louisiade archipelago, Papua New Guinea: Socioeconomic characteristics and management options. Ocean and Coastal Management, 137, 43-56. https://doi.org/10.1016/j. ocecoaman.2016.12.009

Waddell, S. \& EDO NSW. (2016). Legal report on the draft beche-demer fishery management plan (appendix to interactive governance analysis of the beche-de-mer 'fish chain' from Papua New Guinea to Asian markets). Retrieved from https://www.uts.edu.au/about/ faculty-arts-and-social-sciences/research/projects/png-beche-demer-fish-chain. Accessed 25 June 2019.
Weeratunge, N., Béné, C., Siriwardane, R., Charles, A., Johnson, D., Allison, E. H., ... Badjeck, M. C. (2014). Small-scale fisheries through the wellbeing lens. Fish and Fisheries, 15(2), 255-279. https://doi.org/10.1111/faf.12016

Willman, R., Franz, N., Fuentevilla, C., McInerney, T. F. \& Westlund, L. (2017). A human rights-based approach in small-scale fisheries: Evolution and challenges in implementation. In S. Jentoft, S. Chuenpagdee, R. Barragan-Paladines, M. J. Franz (Eds.). The small scale fisheries guidelines: Global implementation (pp. 763-787). Dordrecht: Springer.

Publisher's Note Springer Nature remains neutral with regard to jurisdictional claims in published maps and institutional affiliations. 